Anna Reiwer-Kaliszewska

Wyższa Szkoła Administracji i Biznesu

im. Eugeniusza Kwiatkowskiego, Gdynia

areiwer@yahoo.co.uk

\title{
Opodatkowanie podatkiem dochodowym od osób fizycznych wynagrodzenia $z$ tytułu obciążenia nieruchomości służebnością przesyłu - zarys ewolucji problematyki
}

DOI: http://dx.doi.org/10.12775/SIT.2017.039

\section{Uwagi wprowadzające}

Z dniem 3 sierpnia 2008 r. weszły w życie przepisy art. 3051-3054 k.c., dodane przez art. 1 pkt 2 Ustawy $z$ dnia 30 maja 2008 r. o zmianie ustawy - Kodeks cywilny oraz niektórych innych ustaw ${ }^{1}$. W przepisach tych uregulowano problematykę tzw. służebności przesyłu. W ślad za wprowadzeniem do Kodeksu cywilnego nowych przepisów nie zaproponowano jednak odpowiednich zmian w treści ustawy o podatku dochodowym od osób fizycznych (dalej: u.p.d.o.f.). $Z$ tego powodu problematyka ta budziła wiele wątpliwości prawnych i była przyczyną sporów między podatnikami a organami podatkowymi.

Dopiero 4 października 2014 r. dodano do art. 21 ust. 1 u.p.d.o.f. punkt 120a, w którym zwolniono z podatku dochodowego wynagrodzenie otrzymane za ustanowienie służebności przesyłu w rozu-

${ }^{1}$ Dz.U. Nr 116, poz. 731. 
mieniu przepisów prawa cywilnego. Nowelizacja ta była skutkiem ugruntowanej linii orzeczniczej sądów administracyjnych.

Celem niniejszego artykułu jest próba przeanalizowania ewolucji opodatkowania wynagrodzenia $z$ tytułu ustanowienia służebności przesyłu podatkiem dochodowym od osób fizycznych na przełomie ostatnich lat.

\section{Uregulowanie służebności przesyłu w Kodeksie cywilnym}

Problematyka służebności przesyłu została uregulowana w Kodeksie cywilnym w 2008 roku. Wtedy to, z dniem 3 sierpnia 2008 r., weszły w życie przepisy art. 3051-3054 k.c., dodane przez art. 1 pkt 2 Ustawy z dnia 30 maja 2008 r. o zmianie ustawy - Kodeks cywilny oraz niektórych innych ustaw. Wprowadzono w ten sposób do Kodeksu cywilnego, do występujących już wcześniej służebności gruntowych, przysługujących każdoczesnemu właścicielowi oznaczonej nieruchomości władnącej oraz służebności osobistych, przysługujących oznaczonym osobom fizycznym, trzeci rodzaj służebności - służebność przesyłu².

Zgodnie $z$ art. 244 k.c. służebność obok użytkowania, zastawu i spółdzielczego własnościowego prawa do lokalu jest ograniczonym prawem rzeczowym. Zdaniem Bartosza Rakoczego ustawodawca mógł problematykę służebności przesyłu uregulować, korzystając $z$ instrumentów prawa zobowiązań i wprowadzając nowy typ umowy nazwanej, jednakże zdecydował się na ograniczone prawo rzeczowe, przede wszystkim $z$ uwagi na fakt, iż prawo rzeczowe zapewnia większą stabilność objętych nim stosunków prawnych, chciał także uniezależnić prawo przedsiębiorcy do korzystania $z$ cudzego gruntu od często zmiennej i nieprzewidywalnej woli właściciela ${ }^{3}$.

${ }^{2}$ E. Gniewek, Prawo rzeczowe, Warszawa 2016, s. 260-261. Na temat genezy służebności przesyłu zob.: M. Biernacki, Służebność przesyłu jako ograniczone prawo rzeczowe - kolaż prawniczy, „Rejent” 2010, nr 4, s. 9 i n.; E. Gniewek, System prawa prywatnego. Prawo rzeczowe, t. 4, Warszawa 2012, s. 260-261.

${ }^{3}$ B. Rakoczy, Służebność przesyłu w praktyce, Warszawa 2012, s. 15-17. 
Zgodnie z wprowadzonym w 2008 r. do Kodeksu cywilnego art. 3051 nieruchomość można obciążyć na rzecz przedsiębiorcy, który zamierza wybudować lub którego własność stanowią urządzenia, o których mowa w art. $49 \S 1$ k.c. (urządzenia doprowadzające tzw. media, czyli np. gaz, energię elektryczną) prawem polegającym na tym, że przedsiębiorca może korzystać w oznaczonym zakresie $z$ nieruchomości obciążonej, zgodnie $z$ przeznaczeniem tych urządzeń (służebność przesyłu). Oznacza to, że przedsiębiorca zostaje uprawniony do wybudowania i późniejszej eksploatacji urządzeń przesyłowych na cudzej nieruchomości, co wiąże się również z prawem wstępu na cudzy grunt w celu wybudowania i konserwacji tych urządzeñ ${ }^{4}$. Istotą służebności przesyłu jest to, że służy wyważeniu sprzecznych interesów - interesu publicznego, jakim jest budowa i wykorzystanie urządzeń przesyłowych, oraz interesu właściciela gruntu, którym najczęściej jest właściciel prywatny ${ }^{5}$.

W odróżnieniu od służebności gruntowych służebność przesyłu ustanawia się na rzecz przedsiębiorców przesyłowych, a nie na rzecz właściciela innej nieruchomości ${ }^{6}$. Ponadto nie występują tu nieruchomości władnąca i podporządkowana, a zatem nie obowiązuje zasada, zgodnie z którą służebność może mieć na celu jedynie zwiększenie użyteczności nieruchomości władnącej ${ }^{7}$. Ustanowiona

${ }^{4}$ A. Brzozowski, W. J. Kocot, W. Opalski, Prawo rzeczowe. Zarys wykładu, Warszawa 2012, s. 197.

${ }^{5}$ B. Rakoczy, op. cit., s. 20.

${ }^{6}$ Służebność gruntowa została uregulowana w art. 285 k.c., zgodnie z którym nieruchomość można obciążyć na rzecz właściciela innej nieruchomości (nieruchomości władnącej) prawem, którego treść polega bądź na tym, że właściciel nieruchomości władnącej może korzystać w oznaczonym zakresie $z$ nieruchomości obciążonej, bądź na tym, że właściciel nieruchomości obciążonej zostaje ograniczony w możności dokonywania w stosunku do niej określonych działań, bądź też na tym, że właścicielowi nieruchomości obciążonej nie wolno wykonywać określonych uprawnień, które mu względem nieruchomości władnącej przysługują na podstawie przepisów o treści i wykonywaniu własności. Służebność gruntowa może mieć jedynie na celu zwiększenie użyteczności nieruchomości władnącej lub jej oznaczonej części.

7 A. Brzozowski, W. J. Kocot, W. Opalski, op. cit., s. 197-198. 
służebność ma umożliwić przedsiębiorcy przesyłowemu prowadzenie działalności gospodarczej przy wykorzystaniu cudzego gruntu ${ }^{8}$.

W przeciwieństwie do służebności osobistych służebność przesyłu nie jest związana nierozerwalnie $z$ osobą uprawnionego i przechodzi na nabywcę przedsiębiorstwa lub urządzeń przesyłowych, ponadto wygasa wraz z zakończeniem likwidacji przedsiębiorstwa. Służebność przesyłu ustanawiana jest najczęściej w drodze umowy (w formie aktu notarialnego) między właścicielem nieruchomości a przedsiębiorcą przesyłowym. Do ustanowienia służebności przesyłu może dojść także w sposób przymusowy. Dokonuje go sąd w toku postępowania nieprocesowego, a postanowienie to ma charakter prawokształtujący ${ }^{9}$.

Zgodnie $z$ rządowym uzasadnieniem projektu ustawy $z$ dnia 30 maja 2008 r. ${ }^{10}$ potrzeba wprowadzenia takiego unormowania wynikała $z$ konieczności jednoznacznego uregulowania ustawowego tej problematyki, co podyktowane było istniejącymi wątpliwościami prawnymi wynikającymi z niedostosowania przepisów o służebności gruntowej do inwestycji liniowych. Zmiana była oczekiwana szczególnie $z$ powodu występowania całej infrastruktury urządzeń przesyłowych umieszczonych przez przedsiębiorstwa państwowe na gruntach prywatnych bez zgody właścicieli tych nieruchomości ${ }^{11}$. W konsekwencji właściciele tych gruntów żądali wynagrodzenia za tzw. bezumowne korzystanie $z$ nieruchomości oraz usunięcia instalacji. Wprowadzone rozwiązania prawne miały pomóc zlikwidować choć część spornych sytuacji ${ }^{12}$.

8 B. Ziemianin, K. A. Dadańska, Prawo rzeczowe, Warszawa 2012, s. 176-177; B. Rakoczy, op. cit., s. 9; E. Gniewek, Prawo rzeczowe.., s. 260-261.

${ }^{9}$ Ibidem, s. 262.

${ }^{10}$ www.sejm.gov.pl (dostęp: 30.09.2017 r.)

${ }^{11}$ Z. Gołba, Stużebności gruntowe, drogowe, osobiste i przesyłu. Zagadnienia prawne, Warszawa 2016, s. 149.

12 B. Baran, Prawo cywilne dla zarządców nieruchomości, Warszawa 2012, s. 126. Zdaniem P. Lewandowskiego celem prawnego uregulowania służebności przesyłu był zamiar ustawodawcy, by ułatwić przedsiębiorcom przesyłowym pozyskiwanie gruntów pod inwestycje przesyłowe bez konieczności zakupu tych nieruchomości. Zob. P. Lewandowski, Służebność przesyłu w prawie polskim, Warszawa 2014, s. 32. 
Ustanowienie nowego rodzaju służebności odnoszącej się do inwestycji dotyczących budowy urządzeń infrastruktury technicznej w sposób ustawowy uregulowało istniejącą już, zapoczątkowaną uchwałą Sądu Najwyższego z 17 stycznia 2003 r. ${ }^{13}$, praktykę ustanawiania służebności gruntowych dla realizacji tych inwestycji.

\section{Opodatkowanie podatkiem dochodowym wynagrodzenia $z$ tytułu służebności przesyłu - stan prawny przed $2014 \mathrm{r}$.}

Na początku niniejszych rozważań wskazać należy, iż przepis art. 21 ust. 1 pkt 120 u.p.d.o.f. dotyczący zwolnień dodany został do ustawy o podatku dochodowym od osób fizycznych przez art. 1 pkt 7 lit. a tiret siódme Ustawy $z$ dnia 18 listopada 2004 r. o zmianie ustawy o podatku dochodowym od osób fizycznych oraz zmianie niektórych innych ustaw $^{14}, \mathrm{z}$ kolei regulacje prawne dotyczące służebności przesyłu zostały wprowadzone do Kodeksu cywilnego $z$ dniem 3 sierpnia 2008 r. Mimo wprowadzenia do Kodeksu cywilnego przepisów dotyczących służebności przesyłu nie dokonano odpowiednich zmian w treści ustawy o podatku dochodowym od osób fizycznych, co spowodowało liczne wątpliwości interpretacyjne.

Zgodnie $z$ brzmieniem art. 21 ust. 1 pkt 120 u.p.d.o.f., wolne od podatku są odszkodowania wypłacone na podstawie wyroków sądowych i zawartych umów (ugód), posiadaczom gruntów wchodzących w skład gospodarstwa rolnego, z tytułu: ustanowienia służebności gruntowej, rekultywacji gruntów, szkód powstałych $\mathrm{w}$ uprawach rolnych i drzewostanie - w wyniku prowadzenia na tych gruntach, przez podmioty uprawnione na podstawie odrębnych przepisów, inwestycji dotyczących budowy infrastruktury przesyłowej ropy naftowej i produktów rafinacji ropy naftowej oraz budowy

${ }^{13}$ III CZP 79/02.

${ }^{14}$ Dz.U. Nr 263, poz. 2619. 
urządzeń infrastruktury technicznej, o których mowa w art. 143 ust. 2 ustawy o gospodarce nieruchomościami ${ }^{15}$.

\section{Stanowisko organów podatkowych}

Organy podatkowe kwalifikowały wynagrodzenia uzyskane w związku z ustanowieniem służebności przesyłu jako przychody z innych źródeł i jako takie podlegające opodatkowaniu ${ }^{16}$.

Stanowisko organów podatkowych, wyrażane głównie w wydawanych interpretacjach prawa podatkowego, opierało się na trzech głównych argumentach. Przede wszystkim organy podatkowe uważały, że fakt, iż służebność przesyłu nie została przez ustawodawcę literalnie wymieniona $\mathrm{w}$ dyspozycji art. 21 ust. 1 pkt 120 u.p.d.o.f., przeświadcza o braku podstaw do zastosowania zwolnienia od podatku dochodowego od osób fizycznych. Przyjęcie odmiennego wniosku zdaniem organów podatkowych prowadziłoby do pogwałcenia art. 84 Konstytucji RP. Wszelkie bowiem zwolnienia i ulgi podatkowe są wyjątkiem od zasady powszechności i równości opodatkowania oraz zasady sprawiedliwości podatkowej, a ich zastosowanie nie może odbywać się na podstawie wykładni rozszerzającej.

Ponadto organy podatkowe podnosiły, iż zamiarem ustawodawcy nie było rozszerzenie zawartego w art. 21 ust. 1 pkt 120 u.p.d.o.f. katalogu zwolnień, gdyż gdyby miał taki zamiar, to rozszerzyłby ten katalog po wprowadzeniu do Kodeksu cywilnego regulacji dotyczącej służebności przesyłu.

Co więcej, organy podatkowe stały na stanowisku, że zwolnieniem podatkowym objęte jest odszkodowanie, rozumiane jako świadczenie należne poszkodowanemu za wyrządzoną mu szkodę, od osoby, która tę szkodę wyrządziła lub ponosi za nią odpowiedzialność, a nie wynagrodzenie za korzystanie $z$ cudzej własność czy oddanie

15 Dz.U. z 2010 r. Nr 102, poz. 651 ze zm.

${ }^{16}$ Zgodnie $z$ art. 9 u.p.d.o.f. opodatkowaniu podatkiem dochodowym podlegają wszelkiego rodzaju dochody, $z$ wyjątkiem dochodów wymienionych w art. 21, 52, 52a i 52c oraz dochodów, od których na podstawie przepisów Ordynacji podatkowej zaniechano poboru podatku. 
w użytkowanie. Prawo do zwolnienia wypłaconego odszkodowania powinno wynikać $z$ tytułu ustanowienia służebności gruntowej, rekultywacji gruntów albo $z$ tytułu szkód powstałych w uprawach rolnych i drzewostanie ${ }^{17}$.

W wydanej 10 lipca 2013 r. interpretacji ogólnej ${ }^{18}$ Minister Finansów uznał, iż wynagrodzenie otrzymane za ustanowienie służebności przesyłu nie korzysta ze zwolnienia od podatku dochodowego, uregulowanego w art. 21 ust. 1 pkt 120 u.p.d.o.f. i podlega opodatkowaniu tym podatkiem na zasadach ogólnych przy zastosowaniu skali podatkowej określonej w art. 27 ust. 1 u.p.d.o.f. jako przychód z innych źródeł, o których mowa w art. 20 ust. 1. Minister Finansów przychylił się do argumentów innych organów podatkowych, uznając, iż służebność przesyłu nie jest rodzajem służebności gruntowej, lecz stanowi trzeci rodzaj służebności uregulowanych w Kodeksie cywilnym i $z$ tego powodu wynagrodzenie $z$ tytułu służebności przesyłu nie może korzystać ze zwolnienia od podatku. Powołał się przy tym na zasadę wykładni expressio unis, zgodnie $z$ którą jeżeli ustawodawca wymienia w przepisie jeden $z$ elementów należący do określonego zbioru, to $z$ zakresu wymienionej normy wyłącza w ten sposób pozostałe, niewymienione elementy. Uznał zatem, że skoro ustawodawca w art. 21 ust. 1 pkt. 120 u.p.d.o.f., dotyczącym zwolnień od podatku dochodowego, wymienił służebność gruntową, a nie uwzględnił $\mathrm{w}$ nim służebności przesyłu, to należy przyjąć, iż wynagrodzenie $z$ tytułu ustanowienia służebności przesyłu nie podlega zwolnieniu od podatku ${ }^{19}$.

17 Stanowisko organów podatkowych było niekiedy potwierdzane przez sądy, zob. np. wyrok Wojewódzkiego Sądu Administracyjnego w Szczecinie z dnia 18 listopada 2009 r. sygn. akt I SA/Sz 631/09. W tej sprawie WSA stwierdził również, iż odesłanie do odpowiedniego stosowania przepisów o służebnościach gruntowych o niczym nie przesądza, gdyż ustawodawca także w wypadku służebności osobistych odsyła do odpowiedniego stosowania przepisów o służebnościach gruntowych, a nie oznacza to przecież, że służebność osobista jest rodzajem służebności gruntowej.

18 DD3/033/101/CRS/13/RWPD-48186/RD-70022/13.

19 Interpretacja ta została zmieniona interpretacją ogólną Ministra Finansów z dnia 21.05.2014 r., www.sejm.gov.pl (dostęp: 30.09.2017 r.). 


\section{Stanowisko przeciwne}

Stanowisko organów podatkowych spotkało się z krytyką nie tylko ze strony samych podatników, uzyskujących wynagrodzenia w związku z ustanowieniem służebności przesyłu, doktryny prawa, lecz także ze strony orzecznictwa sądowo-administracyjnego.

Na szczególną uwagę zasługuje wyrok Naczelnego Sądu Administracyjnego z 1 czerwca 2011 r. ${ }^{20}$, w którym sąd, odwołując się do wykładni historycznej, celowościowej i systemowej, stwierdził, że odszkodowanie wypłacone $z$ tytułu ustanowienia służebności przesyłu objęte jest zwolnieniem od podatku. Zdaniem sądu celem wprowadzenia do polskiego systemu prawnego przepisów o służebnościach przesyłu było prawidłowe zabezpieczenie zarówno interesów przedsiębiorstw - właścicieli sieci przesyłowych, jak i właścicieli nieruchomości, przez które taka sieć miałaby przebiegać. Sąd podkreślił, że przed wprowadzeniem zmian do Kodeksu cywilnego ustanawiano w tym celu służebności gruntowe, choć nie były do końca dostosowane do tych potrzeb. Takie działanie miało oparcie w treści, zaaprobowanej przez doktrynę, uchwały Sądu Najwyższego z 17 stycznia 2003 r.

Naczelny Sąd Administracyjny zwrócił uwagę, iż w chwili ustanowienia przepisu art. 21 ust. 1 pkt 120 u.p.d.o.f. nie było w polskim systemie prawnym instytucji służebności przesyłu. $Z$ tego powodu uznać należy, iż założony cel tegoż przepisu obejmował także zwolnienie $z$ podatku dochodowego wynagrodzenia $z$ tytułu ustanowienia służebności przesyłu. Ponadto zgodnie $z$ art. $305^{4}$ k.c. do służebności przesyłu stosuje się odpowiednio przepisy o służebnościach gruntowych. Zastąpienie w sferze cywilistycznej służebności gruntowej służebnością przesyłu nie zmieniło ani celu, ani treści tych służebności.

Ponadto Naczelny Sąd Administracyjny stwierdził, iż wynagrodzenie wypłacone za ustanowienie służebności przesyłu nie różni się od wypłaty odszkodowania za ustanowienie służebności gruntowej. Świadczenie uzyskane przez osobę fizyczną od przedsiębiorcy re-

${ }^{20}$ II FSK 88/10, Legalis. 
alizującego inwestycję liniową może być bowiem nazwane w różny sposób (np.: zapłata, należność, odszkodowanie, wynagrodzenie, ekwiwalent) i niezależnie od sposobu nazwania w umowie przy zwolnieniu podatkowym należy ustalić materialną istotę tego świadczenia. Tym samym przez odszkodowanie czy też wynagrodzenie należy rozumieć świadczenie pieniężne otrzymane przez osobę fizyczną, posiadacza gruntów wchodzących w skład gospodarstwa rolnego, będącego ustalanym szacunkowo, „z góry”, odszkodowaniem za ograniczenie swego prawa własności do takiej nieruchomości na rzecz przedsiębiorcy liniowego. Omawiane zwolnienie podatkowe dotyczy gruntów wchodzących w skład gospodarstwa rolnego, a grunty takie przynajmniej potencjalnie stanowią dla ich posiadacza środki służące do uzyskiwania przychodu. Zatem wynagrodzenie stanowi odszkodowanie za szkody, jakie posiadacz gruntów rolnych poniesie wskutek realizacji inwestycji liniowej, szczególnie za utracone korzyści, które mógłby uzyskać, gdyby nie doszło do realizacji tej inwestycji (lucrum cessans), stanowiące, obok straty, element ogólnego cywilistycznego pojęcia szkody.

Również w doktrynie prawa wskazywano, iż intencją ustawodawcy nie było wzmacnianie „zwykłych” służebności gruntowych kosztem służebności przesyłu, ale zwolnienie od podatku wynagrodzenia związanego $z$ szeroko rozumianym ograniczeniem możliwości korzystania $\mathrm{z}$ nieruchomości, a różnicowanie skutków zwolnienia w zależności od typu służebności stanowi przejaw nadmiernego fiskalizmu ${ }^{21}$.

$Z$ kolei w wyroku z 29 września 2011 r. ${ }^{22}$ Naczelny Sąd Administracyjny orzekł, że zwolnienie podatkowe przewidziane w art. 21 ust. 1 pkt 120 u.p.d.o.f. nadal, tj. po 3 sierpnia 2008 r., dotyczyło ustanawianej po tej dacie służebności przesyłu, także wobec braku możliwości ustanowienia służebności gruntowej dla realizacji inwestycji, o których mowa w tym przepisie. Odmienna interpretacja uczyniłaby przepis martwym, wobec tego pozostawienie po 3 sierpnia 2008 r. wskazanej normy prawnej w niezmienionym brzmieniu interpretować należało jako brak zamiaru ustawodawcy, by wyeli-

${ }^{21}$ S. Brzeszczyńska, Nieruchomości. Aspekty podatkowe i cywilnoprawne, Warszawa 2012, s. 42-43.

${ }^{22}$ II FSK 654/10 CBOSA. 
minować przedmiotowe zwolnienie podatkowe i de facto objęcie nim również służebności przesyłu.

Stanowisko zaprezentowane we wskazanych orzeczeniach Naczelny Sąd Administracyjny podtrzymał także w wyroku z dnia 25 czerwca 2013 r. $^{23}$ oraz w wyroku $z$ dnia 26 listopada 2013 r. $^{24}$ Stanowisko to podzielały także inne sądy administracyjne ${ }^{25}$.

Pod wpływem jednolitej i utrwalonej linii orzecznictwa sądownictwa administracyjnego w omawianej kwestii Minister Finansów dokonał zmiany stanowiska zwartego w interpretacji ogólnej z 10 lipca 2013 r., wydając kolejną interpretację ogólną z 21 maja 2014 r. ${ }^{26}$, w której uznał, że wynagrodzenie wypłacone $z$ tytułu obciążenia nieruchomości służebnością przesyłu podlega zwolnieniu od podatku dochodowego od osób fizycznych.

\section{Obecny stan prawny}

W dniu 4 października 2014 r. dodano do art. 21 ust. 1 u.p.d.o.f. punkt 120a, w którym zwolniono z podatku dochodowego wynagrodzenie otrzymane za ustanowienie służebności przesyłu w rozumieniu przepisów prawa cywilnego ${ }^{27}$. Nowelizacja ta była skutkiem ugruntowanej linii orzeczniczej sądów administracyjnych ${ }^{28}$. Zmiana miała zastosowanie do dochodów uzyskanych od dnia 1 stycznia 2014 r. Obecnie zatem nie ulega już wątpliwości, iż wynagrodzenie otrzymane za ustanowienie przesyłu w rozumieniu przepisów prawa cywilnego jest wolne od podatku dochodowego od osób fizycznych ${ }^{29}$.

${ }^{23}$ II FSK 2131/11.

${ }^{24}$ II FSK 3050/11.

${ }^{25}$ Zob. np. wyrok WSA w Warszawie z 24.05.2011 r., III SA/Wa 2493/10; wyrok WSA w Szczecinie z 6.04.2011 r., I SA/ Sz 949/10.

${ }^{26}$ DD3/033/126/CRS/14/RD-46264/14.

27 Artykuł 21 ust. 1 pkt 120a został dodany ustawą z dnia 29.08.2014 r. (Dz.U. z 2014 r. Poz. 1328), która weszła w życie 4.10.2014 r., ma zastosowanie do dochodów uzyskanych od dnia 1.01.2014 r.

${ }^{28}$ R. Kubacki, Leksykon. Podatek dochodowy od osób fizycznych, Wrocław 2016, s. 1138-1139.

29 A. Nowak-Piechota, Komentarz do ustawy o podatku dochodowym od osób fizycznych, Gdańsk 2015, s. 349-350. 


\section{Wnioski końcowe}

Przedstawione uwagi dotyczące opodatkowania podatkiem dochodowym od osób fizycznych wynagrodzenia za ustanowienie służebności przesyłu świadczą o tym, że nie zawsze ustawodawca nadąża $\mathrm{z}$ wprowadzeniem zmian $\mathrm{w}$ prawie podatkowym $\mathrm{w}$ ślad za zmianami, które wprowadzone zostały w innych dziedzinach prawa, co może prowadzić do sporów między podatnikami a organami podatkowymi. Mimo wszystko ciekawe jest to, że Ministerstwo Finansów mimo jednolitego orzecznictwa sądów administracyjnego potwierdzało swój odmienny pogląd w przedmiotowej sprawie, wydając interpretację ogólną z dnia 13 maja 2013 r. Dopiero pod wypływem jednolitej i utrwalonej linii orzecznictwa sądownictwa administracyjnego w omawianej kwestii Minister Finansów wydaną przez siebie interpretację ogólną przepisów prawa podatkowego zmienił i uznał, że wynagrodzenie wypłacone $\mathrm{z}$ tytułu obciążenia nieruchomości służebnością przesyłu podlega zwolnieniu od podatku.

Wskazane w niniejszym artykule kwestie świadczą także o dużej roli orzecznictwa sądów administracyjnych, które doprowadziło do wprowadzenia zmian do ustawy o podatku dochodowym od osób fizycznych poprzez dodanie do art. 21 ust. 1 u.p.d.o.f. punktu 120a, w którym zwolniono $z$ podatku dochodowego wynagrodzenie otrzymane za ustanowienie służebności przesyłu w rozumieniu przepisów prawa cywilnego. Zmianę tę należy ocenić jednoznacznie pozytywnie.

\section{STRESZCZENIE}

Opodatkowanie podatkiem dochodowym od osób fizycznych wynagrodzenia $z$ tytułu obciążenia nieruchomości służebnością przesyłu - zarys ewolucji problematyki

Celem niniejszego artykułu jest próba przeanalizowania ewolucji opodatkowania wynagrodzenia $z$ tytułu ustanowienia służebności przesyłu podatkiem dochodowym od osób fizycznych od momentu wprowadzenia do Kodeksu cywilnego przepisów regulujących problematykę tzw. służeb- 
ności przesyłu w 2008 r. aż do nowelizacji ustawy o podatku dochodowym od osób fizycznych w 2014 r. W pracy dokonano analizy obowiązujących przepisów oraz przedstawiono przeciwstawne stanowiska organów podatkowych, podatników oraz sądów administracyjnych w omawianej materii.

Słowa kluczowe: służebność przesyłu; opodatkowanie służebności z tytułu obciążenia nieruchomości służebnością przesyłu; podatek dochodowy od osób fizycznych; zwolnienie od podatku dochodowego od osób fizycznych; wynagrodzenie; odszkodowanie

\section{SUMMARY}

Personal income taxation of revenue relating to transmission easement income - outline of problems in Polish tax regime

The aim of this article is to examine the evolution of the personal income taxation of remuneration for the establishment of easement of transmission services under personal income tax since the introduction into the Civil Code of provisions governing the issue in the year 2008 up to the amendment to the Personal Income Tax Act in year 2014. The paper analyzes the applicable regulations and presents the opposing views of tax authorities, taxpayers, and administrative courts in the matters discussed.

Keywords: transmission easement; personal income tax; exemption from personal income tax; compensation

\section{BIBLIOGRAFIA}

Baran B., Prawo cywilne dla zarządców nieruchomości, Warszawa 2012. Biernacki M., Służebność przesyłu jako ograniczone prawo rzeczowe - kolaż prawniczy, „Rejent” 2010, nr 4.

Brzeszczyńska S., Nieruchomości. Aspekty podatkowe i cywilnoprawne, Warszawa 2012.

Brzozowski A., Kocot W. J., Opalski W., Prawo rzeczowe. Zarys wykładu, wyd. 1, Warszawa 2012.

Gniewek E., Prawo rzeczowe, Warszawa 2016.

Gniewek E., System prawa prywatnego. Prawo rzeczowe, t. 4, Warszawa, 2012. 
Gołba Z., Stużebności gruntowe, drogowe, osobiste i przesyłu. Zagadnienia prawne, Warszawa 2016.

Kubacki R., Leksykon. Podatek dochodowy od osób fizycznych, Wrocław 2016.

Lewandowski P., Służebność przesyłu w prawie polskim, Warszawa 2014. Nowak-Piechota A., Komentarz do ustawy o podatku dochodowym od osób fizycznych, Gdańsk 2015.

Rakoczy B., Stużebność przesyłu w praktyce, Warszawa 2012.

Ziemianin B., Dadańska K. A., Prawo rzeczowe, Warszawa 2012. 
